\title{
Mahasiswa Dan Gaya Kepemimpinan Dalam Organisasi Mahasiswa
}

\author{
Jayaning Sila Astuti ${ }^{1}$ \\ ${ }^{1}$ Program Studi Psikologi Universitas Trunojoyo Madura \\ 1jayaning.astuti@trunojoyo.ac.id
}

\begin{abstract}
Organization $X$ is one of the student activity units in Malang. The results of interviews with two members of the Organizational Advisory Council demonstrated that the general chairman's control over the organization in the 2010 period is weak. In fact, leadership is one of the vital factors in running a stable leadership wheel. The purpose of this study is to find out how the leadership style of students in organization $X$ in the 2010 management period. The leadership style can be mapped after observing how they communicate, provide motivation, set group goals, and make decisions. Therefore, before we could determine a leadership style, it is necessary to know how the previously four mentioned things were carried out in an organization.

This study uses a qualitative descriptive approach with a phenomenological perspective. The research is conducted in organization $X$ in Malang. The data collection tools used are in-depth interviews, observations, and subject reflection journals. To check the validity of the data, observation of diligence, triangulation, and referential adequacy are employed.

The results of this study indicate that the leadership style of organizational $X$ students is group-participatory. This conclusion is drawn after considering: 1) Communication and internal coordination of organizational management that ran in all directions, but went poorly, 2) The most common method of providing motivation is coordination with subordinates, while the typical ones are personal closeness and motivation in the field of writing the subordinates, 3) The goals of the organization are prepared by the general chairman, but he does not provide an explanation to the management under him on the purposes of these goals 4) The way of making decisions in the organization is in a participatory-group style. Other findings in this study are: 1) organization $X$ is an organization that prioritizes talent and interests in comparison to the organizing people, 2) even though the management is weak, the department of talent development for members continues to carry out activities as per its function.
\end{abstract}




\begin{abstract}
Abstrak
Organisasi X adalah salah satu unit kegiatan mahasiswa yang ada di Malang. Berdasarkan hasil wawancara terhadap dua orang anggota Dewan Pertimbangan Organisasi, diketahui bahwa kontrol ketua umum terhadap organisasi pada periode 2010 ini lemah. Padahal kepemimpinan adalah salah satu faktor penting dalam menjalankan roda kepemimpinan secara stabil. Tujuan penelitian ini adalah mengetahui bagaimana gaya kepemimpinan mahasiswa di organisasi $\mathrm{X}$ pada periode kepengurusan 2010. Gaya kepemimpinan dapat dipetakan setelah melihat cara berkomunikasi, cara memberikan motivasi, cara penyusunan tujuan kelompok, dan cara pengambilan keputusan. Oleh karena itu, sebelum dapat menentukan gaya kepemimpinan, perlu untuk mengetahui bagaimana empat hal terjadi dijalankan dalam organisasi.

Penelitian ini menggunakan pendekatan deskriptif kualitatif, dengan perspektif fenomenologi. Lokasi penelitian ini adalah organisasi X di Malang. Alat pengumpulan data yang digunakan adalah wawancara mendalam, observasi, dan jurnal refleksi subyek. Pengecekan keabsahan data dilakukan dengan ketekunan pengamatan, triangulasi, dan kecukupan referensial.

Hasil penelitian ini menunjukkan bahwa gaya kepemimpinan mahasiswa organisasi $\mathrm{X}$ adalah partisipatif-kelompok. Kesimpulan ini diambil setelah mempertimbangkan : 1) Komunikasi dan koordinasi internal pengurus organisasi berjalan ke semua arah, namun berjalan kurang baik, 2) Cara memberikan motivasi yang banyak digunakan adalah koordinasi dengan bawahan, sedang yang khas adalah kedekatan personal dan pemotivasian di bidang kepenulisan bawahan, 3) Tujuan organisasi disusun oleh ketua umum, namun ketua umum tidak memberikan penjelasan pada pengurus di bawahnya mengenai makna dari tujuan tersebut 4) Cara pengambilan keputusan dalam organisasi adalah dengan gaya partisipatifkelompok. Temuan lain dalam penelitian ini adalah :1) organisasi $\mathrm{X}$ adalah organisasi yang mengedepankan bakat minat dibandingkan keorganisasian, 2) meskipun kepengurusan lemah, departemen pengembangan bakat minat anggota tetap melaksanakan kegiatan sebagaimana fungsinya.
\end{abstract}

\title{
Latar Belakang
}

Ada banyak organisasi yang mengalami lemahnya fungsi pemimpin, baik organisasi besar maupun kecil. Salah satunya adalah sebagaimana yang dialami oleh Organisasi Mahasiswa X di Malang. Pada hakekatnya, organisasi mahasiswa adalah organisasi yang beranggotakan mahasiswa untuk mewadahi bakat, minat, dan potensi mahasiswa yang dilaksanakan di dalam kegiatan ekstra kurikuler (Wikipedia, n.d.). Lemahnya fungsi kepemimpinan terutama disebabkan minimnya kontrol pemimpin - atau yang disebut sebagai ketua umum - dalam organisasi ini. Masalah ini diketahui setelah melakukan observasi pra-penelitian pada minggu 
keempat bulan September dan minggu pertama bulan Oktober 2010 serta melalui perbincangan dengan beberapa anggota yaitu WW dan SP sebagai Dewan Pertimbangan Organisasi (DPO) organisasi X tersebut. DPO adalah suatu bagian dalam organisasi yang memberikan pertimbangan serta saran pada ketua umum dan jajarannya apabila dibutuhkan.

Menurut SP, indikator keberhasilan kepengurusan ada empat yaitu, 1) ketika pemimpin mampu meredam masalah tanpa melibatkan orang-orang di luar kepengurusan, 2) program kerja organisasi tidak hanya terlaksana tapi terlaksana secara dinamis, 3) ketika semua departemen dapat bekerja secara bersama dan tidak terjadi perselisihan-perselisihan fatal, 4) pengkaderan anggota berjalan baik (W : SP, GC, 14-1-2010). WW menambahkan poin keguyuban antar pengurus dan anggota sebagai poin kelima dalam kriteria tersebut (W : WW, UKMX, 14-102010).

Dengan kriteria tersebut, SP menyebutkan kurang adanya komunikasi terbuka di antara pengurus dalam organisasi X tersebut. SP juga menyebutkan fakta tentang buruknya koordinasi antar departemen, ketua umum dan pengurus harian yang jarang mewadahi rapat koordinasi sehingga masalah-masalah yang terjadi dalam organisasi lambat atau malah tidak terselesaikan, serta ketua umum yang bersikap lepas tangan terhadap masalah-masalah yang terjadi. Sehingga dari faktafakta yang dia ungkapkan, SP menilai keberhasilan kepengurusan 2010 ini adalah $50 \%$ (W : SPP, GC, 14-10-2010)

Setelah menelaah visi misi kepengurusan, WW menambahkan bahwa titik tolak permasalahan di organisasi X periode 2010 ini adalah komunikasi dan koordinasi, serta pengkaderan anggota. Kurangnya komunikasi dan koordinasi dalam organisasi $\mathrm{X}$ terjadi secara keseluruhan, yaitu antar pengurus, antar anggota, serta antara pengurus dengan anggota. Menurut WW, kepengurusan secara keseluruhan belum berhasil sama sekali. Yang tepat adalah departemen apa yang sudah berhasil dalam kepengurusan ini. Dari fakta-fakta tersebut, WW memberi nilai 4 untuk keberhasilan kepengurusan periode ini direntang dari skala 1-10 (W : WW, UKMX, 14-10-2010) 
Tentang keberadaan pemimpin, SP dan WW mengiyakan bahwa pemimpin memiliki fungsi sentral dalam mengendalikan roda organisasi X serta menangani berbagai masalah yang terjadi di dalamnya. Ini sebagaimana yang dikatakan (Koontz et al., 1996) bahwa pemimpin harusnya memiliki kualitas daya tarik dan pesona yang menimbulkan loyalitas, pengabdian dan keinginan yang kuat dari para pengikut untuk melakukan hal-hal yang diinginkan pemimpin, maka kelemahan fungsi kontrol pemimpin betul-betul akan berakibat fatal bagi keberlangsungan kepengurusan maupun organisasi. (Chaniago, 2017) menyebut pemimpin sebagai seseorang yang dapat mempengaruhi orang lain atau kelompok untuk melakukan pekerjaan secara optimal sebagaimana yang telah ditetapkan sesuai dengan tujuan organisasi.

Visi kepengurusan periode ini adalah mengoptimalkan seluruh komponen untuk mengembangkan kepenulisan dengan manajemen dan jaringan organisasi yang baik. Visi tersebut diimplementasikan dalam tiga misi yaitu, 1) mengembangkan, mempertahankan, dan mengontrol kepenulisan anggota, 2) menyelaraskan kegiatan kepenulisan dengan manajemen organisasi, dan 3) memperluas dan mempertahankan jaringan komunikasi dengan pihak yang terkait untuk pengembangan organisasi. Misi organisasi adalah menampung, membina, mengembangkan bakat dan minat serta yang berkaitan dengan kepenulisan bagi para anggotanya. Kepenulisan yang dikembangkan dalam organisasi ini adalah dalam bidang karya sastra, karya ilmiah, serta jurnalistik.

Pemimpin dalam posisi sentralnya dalam kelompok, memainkan peran penting dalam membentuk tujuan kelompok, ideologi, struktur, dan aktifitas kelompok (Krech et al., 1962). Pemimpin juga memiliki peranan nyata dalam membentuk pola pikiran. Mereka berfungsi sebagai simbol dari kesatuan moral masyarakat. Pemimpin mengekspresikan etika kerja dan nilai-nilai yang merangkul masyarakat. Kenyataan dalam manajemen menunjukkan bahwa kelompok kerja yang dibiarkan sendiri tanpa pemimpin, mereka hanya mencapai beberapa tujuan. Tidak ada satu faktorpun yang memberikan lebih banyak manfaat daripada pemimpin yang efektif (Gibson et al., 1997). Dari pendapat ahli tersebut dapat ditarik asumsi sementara bahwa para anggota akan berusaha sedemikian rupa 
sehingga roda organisasi tetap akan berjalan semestinya apabila memiliki pemimpin yang efektif. Pimpinan di bawah ketua umum terutama, mereka akan melakukan hal yang serupa. Salah satunya dengan mengembangkan model atau gaya kepemimpinannya sendiri.

Dari fenomena tersebut serta asumsi tentang pemimpin-pemimpin di bawah ketua umum akan mengembangkan gayanya sendiri, penelitian ini dimaksudkan untuk memahami bagaimana gaya kepemimpinan para pemimpin yang ada di bawah posisi ketua umum untuk mengarahkan anggota-anggotanya supaya roda organisasi X tetap berjalan. Gaya kepemimpinan menurut Davis dan Newstroom (Chaniago, 2017) merupakan pola tindakan pemimpin secara keseluruhan seperti yang dipersepsikan atau diacu oleh bawahan. Dalam menjalankan gaya kepemimpinan tersebut, pemimpin menjalankan fungsinya dengan filsafat, keterampilan, dan sikap yang beragam. Untuk tujuan tersebut, penulis menggunakan metode penelitian kualitatif fenomenologi, yang nantinya menggunakan deskripsi dalam menjabarkan hasil penelitian.

Organisasi mahasiswa $\mathrm{X}$ adalah organisasi di tingkat universitas. Organisasi mahasiswa $\mathrm{X}$ yang selanjutnya akan lebih mudah disebut dengan organisasi $\mathrm{X}$ ini menaungi tiga bidang kepenulisan, yaitu karya sastra, karya ilmiah, serta jurnalistik. Organisasi ini berdiri pada 7 Mei 1982, dan struktur kepengurusan pada periode 2010 ini terdiri atas ketua umum, ketua I yang menaungi urusan dalam organisasi, ketua II yang menaungi urusan-urusan luar organisasi, serta empat kepala departemen yaitu departemen WK, departemen S, departemen DL, dan departemen OP.

Pertimbangan lainnya mengapa perguruan tinggi dan mengapa mahasiswa yang dipilih untuk diteliti adalah bahwa para pemimpin dunia dicetak di lembagalembaga perguruan tinggi, sebagaimana yang disampaikan oleh Vincent Santoso dalam diskusi LPM dalam rangka Diesnatalis UKM XXVIII tahun 2010. Ditilik dari motto pengembangan keilmuan yang selalu digaungkan, tak heran bila itulah yang diupayakan. Apalagi pada faktanya, perguruan tinggi adalah lembaga pendidikan tertinggi yang diharapkan darinya lahir generasi-generasi terbaik. 
Fokus yang akan diteliti dalam penelitian ini adalah bagaimana gaya kepemimpinan mahasiswa di organisasi mahasiswa X. Menurut (Koontz et al., 1996) dikatakan bahwa untuk dapat menentukan gaya kepemimpinan harus dengan melihat cara para pemimpin tersebut berkomunikasi, memberi motivasi, penyusunan tujuan, serta pengambilan keputusan. Oleh karena itu, empat hal tersebut akan digali lebih dulu sebelum dapat menjawab pertanyaan penelitian mengenai gaya kepemimpinan mahasiswa.

Adapun manfaat penelitian ini secara jangka panjang untuk organisasi tersebut adalah memberikan informasi mengenai gaya kepemimpinan yang dapat digunakan oleh para pemimpin di organisasi X di Malang jika terjadi lagi peristiwa lemahnya kepemimpinan ini pada periode tersebut.

\section{Metode}

\section{Pendekatan dan Model Penelitian}

Pendekatan yang digunakan dalam penelitian ini adalah pendekatan deskriptif kualitatif. Penelitian deskriptif kualitatif ini menggunakan perspektif fenomenologi. Perspektif fenomenologi yaitu sebuah aliran yang mengkaji penampakan atau fenomena yang mana kesadaran dan fenomena tidak terisolasi satu sama lain dan berhubungan secara dialektis (Bungin, 2008). (Yusuf, 2019) menyebut fenomenologi sebagai ilmu tentang gejala atau hal-hal apa saja yang tampak. Fokus penelitian fenomenologi adalah untuk menggali, memahami, dan menafsirkan arti fenomena, peristiwa, dan hubungannya dengan orang-orang biasa dalam situasi tertentu. Dalam penelitian ini, fenomenologi digunakan untuk memperoleh pemahaman yang mendalam mengenai gaya kepemimpinan mahasiswa di Organisasi mahasiswa X.

Lokasi yang dipilih dalam penelitian ini adalah kompleks organisasi mahasiswa di Malang. Hal ini nampak dari fakta bahwa organisasi yang diteliti terletak di kompleks organisasi mahasiswa, yaitu di aula bersama organisasi mahasiswa, sekretariat organisasi $\mathrm{X}$, serta gazebo belakang kompleks organisasi. Berkaitan dengan kesibukan pada subyek, beberapa kali wawancara dilakukan di 
rumah kos subyek. Berdasarkan kriteria yang sesuai dengan tujuan penelitian, peneliti mengambil lima subyek dan beberapa partisipan sebagai significant others. Menurut (Yusuf, 2019) data kualitatif diantaranya mencakup : a) deskripsi mendetail tentang situasi, kejadian, atau peristiwa fenomena tertentu, baik manusianya dan interaksinya dengan manusia lainnya, b) pendapat langsung dari orang yang berpengalaman, pandangannya, sikapnya, kepercayaan, serta jalan pikirannya, c) cuplikan dokumen, arsip, dan sejarahnya, dan d) deskripsi mendetail tentang sikap dan tingkah laku seseorang. Sumber data penelitian adalah subyek penelitian dan partisipan penelitian yang terdiri dari para bawahan dan rekan sekerjanya. Sumber dokumen yang digunakan adalah draft pertanggungjawaban kepengurusan periode 2010 dan bagan kepengurusan periode 2010.

Dalam penelitian ini, karakteristik subyek dipilih berdasarkan kriteria tertentu sesuai dengan tujuan penelitian, yaitu:

1. Merupakan anggota aktif organisasi X

Penelitian ini spesifik terhadap organisasi X. Jika bukan anggota aktif organisasi X, maka yang bersangkutan tidak akan mengerti secara spesifik kondisi internal organisasi.

2. Sedang menjabat sebagai pemimpin, baik pengurus harian maupun kepala departemen pada periode kepengurusan 2010.

\section{Pengumpulan Data}

Dalam penelitian ini, pengumpulan data dilakukan dengan tiga teknik, yaitu, wawancara mendalam, observasi partisipan, serta jurnal refleksi subyek.

Wawancara adalah proses interaksi yang dilakukan dua orang atau lebih, dimana kedua pihak yang terlibat (interviewer dan interviewee) memiliki hak yang sama dalam bertanya dan menjawab (Herdiansyah, 2019). Wawancara yang dilakukan dalam penelitian ini adalah in depth interviewing atau wawancara mendalam, dengan tetap menggunakan batasan wawancara sebagaimana fokus penelitian yang telah ditetapkan.

Observasi menurut Mills (Herdiansyah, 2019) adalah kegiatan yang terencana dan terfokus untuk melihat dan mencatat serangkaian perilaku ataupun 
jalannya system yang memiliki tujuan tertentu, serta mengungkapkan apa yang ada di balik munculnya perilaku dan landasan suatu system tersebut. Observasi dalam penelitian ini memfokuskan pengamatan pada gaya kepemimpinan subyek yang bersangkutan dalam pertemuan-pertemuan yang melibatkan subyek penelitian. Posisi peneliti ialah sebagai peneliti sekaligus anggota organisasi $\mathrm{X}$, sehingga peneliti melakukan observasi partisipan.

Jurnal refleksi subyek (Primastuti, 2009) adalah sebuah jurnal, dimana subyek dapat merefleksikan pikiran dan perasaannya terhadap stimulus berupa pernyataan atau pertanyaan tertentu. Dalam penelitian ini, pertanyaan yang perlu direspon oleh subyek penelitian adalah fokus penelitian itu sendiri. Subyek penelitian dipersilahkan untuk mengisi kolom yang kosong tanpa ada intervensi apapun dari peneliti. Jurnal refleksi subyek diberikan ketika seluruh sesi wawancara dilaksanakan. Metode pengambilan data ini juga berfungsi untuk melakukan pengecekan keabsahan data.

Proses penelitian dilakukan selama 13 minggu, dimulai pada 23 September 2010 dan berakhir pada tanggal 30 Desember 2010. Pengambilan data penelitian diawali dengan observasi dan wawancara pra penelitian pada tanggal 23 September - 7 Oktober 2010, lalu dilanjutkan dengan pengambilan data untuk penelitian serta triangulasi data pada bulan November-Desember 2010. Pengambilan data terhadap subyek penelitian dilakukan dengan tiga cara, yaitu dengan observasi, wawancara, dan jurnal refleksi subyek.

\section{Analisis Data}

Analisis data adalah proses memahami data untuk menarik kesimpulan. Analisis (Bogdan \& Biklen, 1992) mensyaratkan bekerja dengan data, mengorganisasikannya, memecahnya menjadi unit-unit yang bisa ditata, mensintesiskannya, mencari pola, menemukan yang penting dan harus dipelajari, dan memutuskan apa yang akan diberitahukan kepada orang lain.

Metode analisis data dalam penelitian ini menggunakan metode analisis sebagaimana yang dikemukakan (Bogdan \& Biklen, 1992). Analisis data dilakukan secara sistemik progresif. Karena satuan pengamatan dan wawancara bersifat 
harian, maka setiap hari sesudah selesai melakukan pengambilan data, dilakukan analisis data dalam bentuk interpretasi.

Analisis memaknai pentingnya data menggambarkan bagaimana subyek berkomunikasi, memotivasi bawahan, menyusun tujuan kelompok, dan mengambil keputusan. Berdasarkan informasi yang terkumpul pada hari tersebut dan hari-hari sebelumnya, ditetapkan arah dan fokus pengamatan dan wawancara untuk hari berikutnya, sehingga dapat diperoleh data kumulatif yang semakin komprehensif dan bermakna.

Analisis data lapangan ini dilakukan sesudah pengambilan data dianggap memadai. Secara teknis, tahap-tahap analisis data yang dilakukan adalah sebagai berikut : a) pengambilan data lalu dilanjutkan dengan membuat ringkasan data, b) setiap data yang didapatkan diberi kode-kode sesuai topik, c) data dikelompokkan berdasarkan topik, d) dilakukan reduksi data, data yang tidak sesuai dieliminasi (disimpan di tempat tersendiri dan tidak bercampur dengan data yang relevan), e) data yang sudah dikelompokkan diberi makna, lalu disajikan dalam laporan penelitian, f) pada beberapa data yang dikutip langsung, kutipan tersebut diberi kode, contoh kode (W : DAS, UKMX, 12-11-2010) yang artinya wawancara dilakukan terhadap subyek DAS di UKMX pada tanggal 12 November 2010, g) membuat kesimpulan yang menjadi jawaban dari fokus penelitian.

\section{Teknik Pengecekan Keabsahan Data}

Teknik pengecekan keabsahan data dilakukan untuk memenuhi derajat kepercayaan (credibility) penelitian. Dalam penelitian ini, peneliti menggunakan tiga teknik pengecekan keabsahan data yang digunakan, yaitu dengan ketekunan pengamatan, triangulasi data, dan kecukupan referensial. Ketekunan pengamatan adalah mencari secara konsisten interpretasi dengan berbagai cara dalam kaitannya dengan proses analisis yang konstan atau tentatif (Moleong, 2008). Ketekunan pengamatan bermaksud menemukan ciri-ciri dan unsur-unsur dalam situasi yang sangat relevan dengan persoalan atau isu yang sedang dicari dan kemudian memusatkan diri pada hal-hal tersebut secara rinci. Ketekunan pengamatan menyediakan kedalaman. Ketekunan ini dilakukan dengan melakukan observasi 
terhadap situs dan kegiatan-kegiatan organisasi tersebut sebelum dilakukan penelitian serta sepanjang penelitian dilakukan.

Triangulasi merupakan pengecekan keabsahan data yang memanfaatkan sesuatu yang lain di luar data untuk keperluan pengecekan atau sebagai pembanding terhadap data tersebut (Moleong, 2008). Pengecekan keabsahan dalam penelitian ini dilakukan dengan triangulasi metode, yaitu mengecek kebenaran (keabsahan) data dengan memakai beberapa metode pengumpulan data yang berbeda. Metode yang digunakan untuk pengecekan keabsahan adalah dengan metode wawancara mendalam dan dengan jurnal refleksi subyek. Secara teknis, selain menggunakan tiga metode (wawancara, observasi, dan jurnal refleksi) pada subyek, peneliti melakukan triangulasi data dengan wawancara mendalam terhadap bawahan serta rekan yang sejajar dalam kepengurusan.

Kecukupan referensial dalam hal ini dilakukan dengan pembuatan catatan data lapangan dan pembuatan transkrip wawancara. Referensi dapat dianggap cukup apabila data yang terkumpul pada transkrip baru sama dengan data transkrip sebelumnya.

\section{Hasil Penelitian}

Ada lima kategori yang akan dipaparkan dalam hasil penelitian ini. Empat kategori yang meliputi komunikasi, motivasi, penyusunan tujuan, serta pengambilan keputusan ini selanjutnya akan mengarah pada didapatkannya pemahaman mengenai tipe gaya kepemimpinan mahasiswa organisasi X. Kategori yang kelima adalah temuan unik yang didapatkan dalam penelitian.

\section{Komunikasi}

Departemen-departemen di dalam tubuh organisasi mahasiswa $\mathrm{X}$ berjalan dengan koordinasi yang kurang baik. Komunikasi tidak berjalan lancar.

Berikut akan dipaparkan bagaimana komunikasi dan koordinasi antar pimpinan (pengurus harian) dalam organisasi, dan komunikasi antara pimpinan dengan departemen-departemen di bawahnya. 
1. Komunikasi dan koordinasi antara ketua umum dengan ketua I, ketua umum dengan pengurus departemen, serta ketua I dengan bawahan-bawahannya.

Tidak adanya pendampingan dari pengurus harian terhadap pengurus organisasi berlangsung sejak bulan Juni hingga November, sedangkan kepengurusan berlangsung sejak bulan Januari sampai Desember. Keduanya tidak menjalankan fungsinya dalam mendampingi kepengurusan dan kepanitiaan, dan pengurus harian lainnya tidak ada yang menggantikan fungsinya. Ini menggambarkan kurangnya komunikasi antar pimpinan serta antara pimpinan dengan bawahan di organisasi.

2. Komunikasi dan koordinasi antara ketua I dengan pengurus harian lainnya berjalan kurang baik.

Di antara pengurus harian dibentuk piket sekretariat, ketua I mendapat giliran hari Senin, ketua II hari Selasa, dan seterusnya. Pengurus harian yang hadir pada hari giliran piketnya harus memberikan informasi pada pengurus harian lainnya tentang keadaan pada hari tersebut. Faktanya, pengurus harian yang mendapat giliran piket tidak memberikan kabar pada pengurus harian yang lain tentang hasil rapat hari itu, sehingga seringkali terjadi pada suatu rapat, pengurus harian yang hadir tidak dapat mengikuti rapat dengan optimal karena tidak tahu hasil dari rapat sebelumnya.

3. Komunikasi antara kepala departemen dengan anggota departemen.

Ada departemen yang komunikasi internal departemennya berjalan lancar, ada yang tidak berjalan lancar. Komunikasi antara kepala departemen S dan kepala departemen WK dengan bawahan-bawahannya dalam departemen berjalan dengan intens. Pada departemen S, kepala departemen melakukan pendampingan pada tiap acara yang digelar oleh bawahan. Pada departemen WK, kepala departemen sigap dalam mengenali program apa yang mulai tidak berjalan lancar dan sesegera mungkin mengumpulkan anggota departemen untuk membahas pemecahan masalahnya. Pada departemen DL, komunikasi atasan-bawahan yang terjalin dalam departemen kurang berjalan. Tatap muka antar anggota hanya terjadi empat kali selama enam bulan kepengurusan. Keputusan-keputusan 
dirundingkan melalui pesan singkat/facebook, dan sering tidak tertindaklanjuti sesuai dengan rencana.

\section{Motivasi}

1. Tidak semua pemimpin mampu memotivasi bawahan. Motivasi yang bisa menggerakkan kinerja kepengurusan di organisasi $\mathrm{X}$ adalah motivasi dari diri sendiri, serta motivasi dari rekan-rekan satu departemen.

a. Bentuk motivasi ketua umum terhadap pengurus organisasi.

Ketua umum sendiri jarang hadir dalam acara-acara yang digelar oleh departemen. Interaksi ketua umum dengan kepala departemen adalah ketika awal pembentukan kepanitiaan. Dapat dikatakan bahwa sedikitnya motivasi yang dapat dilakukan oleh ketua umum berkenaan dengan sedikitnya waktu interaksi dengan para pengurus organisasi. Bentuk motivasi yang diberikan adalah berupa kata penyemangat terhadap bawahan, serta mengingatkan bawahan terhadap program kerja dengan menanyakan keadaan acara yang digelar melalui pesan singkat.

b. Bentuk motivasi ketua I terhadap organisasi

Ketua I juga jarang hadir dalam acara-acara dalam organisasi. Motivasi yang dilakukan ketua I terhadap bawahan adalah dengan membantu mencarikan dana pinjaman untuk operasional pada bulan November sebelum acara Pameran Karya. Motivasi dalam bentuk pendampingan mulai dilakukan secara intens pada bulan November sebelum acara PK, saat acara berlangsung, dan pasca acara.

c. Bentuk motivasi yang dilakukan kepala departemen WK.

Tugas kepala departemen WK adalah memberikan motivasi kepenulisan terhadap bawahan dan anggota organisasi secara keseluruhan. Ketika para bawahan sudah mulai terkonsentrasi pada tanggungjawabnya dalam kepanitiaan acara besar, kepala departemen WK membantu penanggungjawab acara rutin untuk mengontrol persiapan dan pelaksanaan acara tersebut. Metode tersebut meringankan beban anggota departemen, sehingga anggota menjadi lebih termotivasi memberikan yang terbaik. 
Interaksi yang intens dalam beragam bentuk di atas menciptakan kedekatan personal antar anggota departemen. Koordinasi berjalan dengan lebih baik, dan motivasi yang seperti itu mampu menguatkan dan memelihara kedekatan personal dengan anggota hingga di akhir kepengurusan.

d. Bentuk motivasi di departemen S.

Model motivasi yang dilakukan oleh kepala departemen S adalah dengan selalu hadir saat kegiatan-kegiatan dari departemennya sedang digelar oleh bawahannya. Kepala departemen juga sesering mungkin berkoordinasi dengan bawahan dengan bertanya tentang perkembangan tugas mereka dan rencana pengembangan selanjutnya dari tugas tersebut. Kepala departemen akan memuji ketika bawahan berhasil menjalankan tugasnya, dan menegur bawahan ketika melakukan kesalahan serta memberi pengarahan bagaimana hal tersebut seharusnya dijalankan. Cara lain kepala departemen dalam memotivasi bawahan adalah dengan melakukan pendekatan personal pada bawahan-bawahannya, baik anggota lama atau baru departemennya supaya anggota bersedia bersikap terbuka pada atasan. Pendekatan yang lebih intens terutama dilakukan terhadap anggota baru, sebab biasanya anggota baru masih malu dan takut-takut terhadap anggotaanggota lama.

e. Bentuk motivasi kepala departemen DL

Kepala departemen jarang ada di sekretariat. Meskipun demikian, kepala departemen masih berusaha untuk menyemangati bawahan lewat pesan singkat di ponsel atau facebook untuk menggantikan koordinasi secara langsung.

f. Selain motivasi dari atasan, motivasi dari diri pribadi juga berperan.

Di organisasi $\mathrm{X}$, bawahan tetap dapat menjalankan tugasnya karena yang bersangkutan memiliki kesadaran sendiri terhadap tanggungjawab mereka meskipun tanpa motivasi dari pengurus harian. Oleh karena itu dapat disimpulkan bahwa hal yang memotivasi pengurus organisasi $\mathrm{X}$ tidak hanya dari pimpinan, namun juga dari internal diri individu. 
2. Motivasi yang banyak digunakan dalam organisasi X ini adalah koordinasi atau mengingatkan bawahan secara intens tentang tanggungjawab mereka. Sedang yang khas adalah kedekatan personal dan pemotivasian bawahan dalam bidang kepenulisan.

\section{Penyusunan Tujuan}

1. Tidak ada sinergi tujuan antara ketua umum dengan para pemimpin yang ada di bawahnya.

Visi misi atau tujuan kepengurusan disusun sendiri oleh ketua umum. Namun hal tersebut tidak ditindaklanjuti oleh ketua umum dengan memberikan penjelasan mendetail pada bawahan tentang maksud dari visi misi tersebut. Dari tiga departemen yang diteliti, satu kepala departemen menyusun tujuan kepengurusan untuk departemennya sendiri tanpa melibatkan bawahan maupun atasan yaitu departemen $S$, dan satu kepala departemen menyusun tujuan kepengurusan bersama dengan bawahan yaitu departemen WK dan dalam sudut pandang mereka tujuan kepengurusan adalah apa yang tersirat dari program kerja. Pada departemen DL, kepala departemen tidak menyusun tujuan departemen, dan memilih untuk membuat program sama dengan periode sebelumnya.

2. Pemimpin tidak dapat menjaga kekompakan pengurus dalam melaksanakan tujuan kepengurusan yang telah ditetapkan karena tidak intensnya komunikasi atasan dengan bawahan.

Tidak ada komunikasi yang intens antara pengurus harian dengan pengurus di bawahnya. Masing-masing kepala departemen mengarahkan anggota pengurus dalam departemennya sendiri untuk mencapai tujuan yang disusunnya untuk departemen. Departemen $\mathrm{S}$ dan departemen WK mampu tetap menjalankan departemennya meski tidak memahami secara pasti tujuan kepengurusan yang dibuat oleh ketua umum. Namun pengurus harian sebagai komando tertinggi tidak dapat menjalankan fungsinya dengan baik sehingga terjadi ketidakteraturan dalam organisasi. 


\section{Pengambilan Keputusan}

1. Cara pengambilan keputusan yang khas di organisasi mahasiswa $\mathrm{X}$ adalah pengambilan keputusan secara bersama.

Di organisasi ini, pengambilan keputusan dilakukan secara bersama. Hal ini mungkin berkaitan dengan kultur kekeluargaan yang tumbuh di organisasi X yang merupakan organisasi bakat minat, sehingga segala sesuatu selalu diupayakan untuk dilakukan dan diselesaikan bersama. Meskipun demikian, pada keadaan-keadaan tertentu para pemimpin mengambil keputusan sendiri yaitu pada saat dibutuhkan keputusan cepat dan bawahan tidak dapat berkumpul.

2. Beberapa pemimpin melimpahkan tanggungjawab pelaksanaan program kerja terhadap bawahan dengan sedikit kontrol atau tanpa kontrol sama sekali, termasuk dalam penentuan segala kebijakan.

Ketua umum serta pengurus harian lainnya jarang hadir dalam rapat evaluasi internal departemen serta acara-acara yang digelar oleh departemen semenjak awal kepengurusan sampai akhir kepengurusan, dan hanya beberapa kali ikut terlibat dalam pengambilan kebijakan. Ketua I yang menaungi urusan internal organisasi demikian juga. Oleh karena itu, hampir Sebagian besar keputusan dan hal-hal teknis dalam organisasi dibuat dan dijalankan oleh internal departemen yang mencanangkan program tersebut.

3. Keputusan bersama yang dijalankan secara konsisten adalah yang dikontrol oleh kepala departemen/koordinator baik melalui pesan singkat maupun pertemuan-pertemuan koordinasi.

Pada departemen WK dan departemen S, keputusan serta pengambilan kebijakan diambil atasan bersama dengan bawahan kecuali pada saat-saat tertentu. Contoh dari saat-saat tertentu ini adalah ketika dibutuhkan keputusan cepat sedangkan para bawahan tidak dapat berkumpul, atau ketika para bawahan sudah terkonsentrasi pada tanggungjawabnya dalam kepanitiaan maka kepala departemen selalu menyiapkan alternative solusi bagi bawahan jika ada acara yang belum 
sempat disiapkan dengan baik. Kedua kepala departemen tersebut hanya melaporkan keputusan final yang telah diambil kepada pengurus harian.

Pada departemen DL, pengambilan keputusan dilakukan bersamasama antara kepala departemen dengan anggota departemen. Namun keputusan-keputusan tersebut banyak yang tidak berjalan, sehingga kepala departemen langsung memberikan instruksi pada bawahan setelah diketahui kendalanya.

\section{Temuan Lain}

1. Organisasi $X$ adalah organisasi yang lebih mengedepankan pengembangan bakat minat anggotanya daripada keorganisasiannya.

Organisasi $\mathrm{X}$ adalah organisasi yang lebih mengedepankan pengembangan bakat minat anggota daripada keorganisasian. Hal ini berkaitan dengan tujuan awal didirikannya organisasi mahasiswa $\mathrm{X}$ yaitu untuk pengembangan bakat minat mahasiswa. Juga bahwa organisasi organisasi tetap berjalan meski ketua umum dan pengurus harian yang lain tersebut tidak menjalankan komunikasi secara intensif dengan bawahan, tidak memberikan motivasi intensif terhadap bawahan, serta tidak terlalu banyak terlibat dalam pengambilan keputusan atau kebijakan di tubuh kepengurusan dan organisasi. Yaitu dengan tetap berjalannya dua departemen yang secara langsung menangani olah kepenulisan di UKM yaitu departemen S dan departemen WK.

2. Para pemimpin di organisasi $X$ memahami tentang kepemimpinan, namun tidak semua dapat mengimplementasikannya.

Menurut ketua I, komunikasi terhadap bawahan adalah penyampaian program kerja, membahas cara pelaksanaannya, dan memikirkan solusi secara bersama ketika terjadi permasalahan. Dalam sudut pandang kepala departemen S, komunikasi dengan bawahan adalah transfer informasi antara atasan dan bawahan. Sedang tugas seorang ketua adalah menentukan dasar-dasar gerakan setahun ke depan yang kemudian akan dijalankan oleh bawahan. Dalam sudut pandang kepala departemen WK 
adalah koordinasi antara pemimpin yang dipimpin. Pemimpin harus memiliki tanggung jawab bagaimana agar bawahannya itu menjalankan tugas sesuai sistem yang berlaku. Dalam sudut pandang kepala departemen DL adalah instruksi antara pimpinan dan bawahan. Dan pada orang beberapa di posisi sentral, pemahaman yang seperti itu belum cukup untuk menjalankan roda organisasi.

3. Pembagian wewenang dan deskripsi tugas pada masing-masing jabatan dalam struktur kepengurusan di organisasi X kurang jelas, sehingga terjadi ketidakjelasan pekerjaan.

Salah satunya adalah ketua I. Wewenang ketua I yaitu menaungi semua urusan dalam organisasi. Namun karena tidak ada penjelasan mendetail mengenai wewenang menaungi ini maka para bawahan langsung menghubungi ketua umum tanpa melibatkan ketua I untuk pengambilan keputusan dan pertimbangan atas kebijakan-kebijakan dalam organisasi. Kurang jelasnya deskripsi jabatan ini juga terjadi pada jabatan ketua departemen. Para ketua departemen menjalankan tugas berdasarkan pengetahuan mereka tentang jabatan tersebut di periode sebelumnya.

4. Sebagai organisasi, organisasi $X$ tidak memiliki sistem keanggotaan yang formal yang mengikat.

Pada organisasi $\mathrm{X}$, anggota baru bisa langsung aktif pasca rekrutmen. Fenomena yang terjadi, sangat mungkin anggota yang sudah aktif selama beberapa bulan lalu tiba-tiba tidak aktif, lalu kembali aktif beberapa bulan kemudian. Begitu juga sebaliknya. Ada juga beberapa anggota dinyatakan lulus proses rekrutmen secara penuh setelah dia duduk sebagai pengurus, meskipun secara normatif hal itu tidak diijinkan oleh prosedural organisasi.

5. Keterlibatan para senior terhadap organisasi organisasi $\mathrm{X}$ tergolong tinggi.

Ketika kontrol dan pendampingan dari pengurus harian terhadap kepengurusan tidak terjadi secara intens, para bawahan memilih untuk berkonsultasi dengan senior atau DPO organisasiyang sering datang ke sekretariat organisasi X. Kultur yang berkembang di organisasi X adalah 
meski sudah tidak menjabat sebagai pengurus, semua orang yang pernah menjadi anggota organisasi $\mathrm{X}$ bebas datang ke sekretariat organisasi.

6. Tugas utama mahasiswa adalah yang berkaitan dengan bidang akademik.

Menyusun skripsi, melaksanakan Praktek Pengalaman Lapangan (PPL) adalah dua di antara kewajiban akademik yang harus dijalani oleh mahasiswa. Ketua umum organisasi $\mathrm{X}$ tidak dapat menjalankan fungsinya dalam kepengurusan dikarenakan kewajiban akademik berupa harus menyelesaikan skripsi, serta ada pekerjaan sambilan. Ketua I tidak dapat menjalankan kewajibannya pada organisasi karena harus menyelesaikan skripsi, serta melaksanakan PPL.

\section{Pembahasan}

Dari gambaran komunikasi internal organisasi X yaitu bahwa departemendepartemen dalam tubuh organisasi $\mathrm{X}$ yang telah dipaparkan di hasil penelitian, dapat dikatakan bahwa komunikasi internal organisasi X berjalan ke semua arah. Ada komunikasi dari bawahan pada atasan, dari atasan pada bawahan, maupun pada rekan sekerja. Dalam (Koontz et al., 1996) disebutkan bahwa pada pemimpin dengan tipe partisipatif-kelompok, pemimpin ini menjalankan komunikasi dua arah dengan bawahan dan dengan rekan sekerja. Artinya, dari aspek komunikasi para pemimpin di organisasi $X$ menggunakan gaya kepemimpinan partisipatifkelompok.

Hasil penelitian menunjukkan bahwa komunikasi antara pemimpin - dalam hal ini adalah pengurus harian organisasi - terhadap bawahan sangat minim. Hal ini membuat aliran informasi dari atas ke bawah dan dari bawah ke atas tidak lancar bahkan sering hilang. Ini sesuai dengan pendapat (Kaswan, 2017) bahwa aliran informasi dari atas ke bawah seringkali hilang ataupun terdistorsi. Komunikasi dalam organisasi diperlukan paling tidak untuk membuat perencanaan, penentuan tujuan, dan program organisasi yang akan diimplementasikan, menjawab dan menjelaskan berbagai kritik, keluhan dan masukan, serta menginformasikan langkah untuk menjaga dan mempertahankan strategi pencapaian tujuan dengan semua pihak yang bertanggungjawab (Kaswan, 2017). Dengan kata lain, meskipun 
para pemimpin organisasi $\mathrm{X}$ menggunakan gaya kepemimpinan partisipatifkelompok, kondisi komunikasi yang sangat minim berpotensi mengganggu perencanaan organisasi hingga upaya organisasi untuk dapat mencapai tujuannya.

Dalam organisasi $\mathrm{X}$, cara-cara yang digunakan untuk melakukan pemotivasian terhadap bawahan berupa kata-kata penyemangat, koordinasi intensif, pendekatan personal pada tiap-tiap bawahan, pendampingan terhadap bawahan, pengambil alihan program kerja tatkala bawahan keberatan dengan tanggungjawab tersebut, pendekatan personal, pemotivasian bawahan di bidang kepenulisan, serta pelibatan bawahan. Pemimpin bisa menggunakan beberapa cara sekaligus dalam satu kesempatan.

Dari empat jenis motivasi dalam organisasi yang diidentifikasi Likert (Koontz et al., 1996) yaitu rasa takut, imbalan, hukuman, dan pelibatan bawahan, yang banyak digunakan di organisasi $\mathrm{X}$ adalah pelibatan bawahan. Pemotivasian dalam bentuk imbalan di organisasi X berupa ucapan terima kasih dan sikap baik, sedangkan hukuman yang digunakan adalah dalam bentuk teguran atau marah ketika bawahan berbuat kesalahan. Cara pemotivasian dalam bentuk rasa takut dan imbalan ekonomi tidak digunakan.

Menurut Maslow (Alwisol, 2007), ada lima hierarki kebutuhan yang memotivasi perilaku manusia yaitu kebutuhan fisiologis, kebutuhan keamanan, kebutuhan dimiliki dan cinta, kebutuhan harga diri, dan kebutuhan aktualisasi diri. Bentuk motivasi pada organisasi $\mathrm{X}$ ini memang tidak termasuk dalam kategori motivasi menurut Likert, namun termasuk bentuk motivasi menurut Maslow yaitu dalam kebutuhan dimiliki dan cinta serta kebutuhan aktualisasi diri.

Adanya perbedaan antara bentuk motivasi yang dijalankan di organisasi $\mathrm{X}$ dengan bentuk motivasi yang dijadikan dasar klasifikasi oleh Likert, maka aspek motivasi ini tak bisa diikutsertaan sebagai salah satu indikasi bagi penetapan gaya kepemimpinan di organisasi X.

Pada penyusunan tujuan dalam organisasi $\mathrm{X}$ diketahui bahwa tidak ada sinergi tujuan antara ketua umum dengan para pemimpin yang ada di bawahnya. Ketua umum tidak memberikan penjelasan menegnai visi misinya, sehingga para pemimpin di bawahnya termasuk kepala departemen menentukan sendiri tujuannya 
berdasarkan pengetahuan mereka sebelumnya. Penentuan tujuan yang saling lepas satu sama lain inilah yang membuat sinergi organisasi tidak terjadi.

Peristiwa-peristiwa yang terjadi merupakan rangkaian sebab akibat. Yang dilakukan oleh ketua umum akhirnya mempengaruhi yang dilakukan oleh para bawahan. Maka dapat dikatakan bahwa aspek ini tidak dapat digunakan sebagai salah satu indikasi gaya kepemimpinan, sebab tiap pemimpin memiliki cara sendiri untuk menentukan tujuan, meski hal itu tidak lepas dari yang dilakukan oleh pucuk pimpinan.

Paparan di atas didukung oleh (Gibson et al., 1997), yang menyatakan bahwa kelompok kerja yang dibiarkan tanpa pemimpin hanya akan mencapai beberapa tujuan, dan tidak ada satu faktor pun yang memberikan lebih banyak manfaat daripada pemimpin yang efektif. Krech, Crutchfield, \& Ballachey (Koontz et al., 1996) menyebutkan bahwa pemimpin memainkan peran penting dalam membentuk tujuan kelompok, ideologi, struktur, dan aktifitas kelompok.

Pola pengambilan keputusan di organisasi $\mathrm{X}$ yang khas adalah cara pengambilan keputusan yang selalu dilakukan bersama, meskipun pada saat-saat tertentu atasan melakukan pengambilan keputusan sendiri. Pada beberapa atasan, saat-saat tertentu tersebut lebih banyak disebabkan oleh bawahan yang tidak dapat berkumpul atau tidak dapat memberikan pertimbangan pada saat keputusan cepat harus diambil. Pada salah satu pemimpin yang lain, keputusan selalu dilakukan bersama dengan bawahan. Jika tak bisa dengan seluruhnya maka dengan bawahan yang saat itu ada dan bisa dihubungi. Hal ini sejalan dengan penuturan (Chaniago, 2017) bahwa Teknik partisipatif dalam pengambilan keputusan ialah teknik dimana individu atau kelompok dilibatkan secara intelektual dan emosional dalam proses pengambilan keputusan. Seberapa besar partisipasi anggota kelompok ini sangat bervariasi.

Di sisi lain, ada pemimpin yang melimpahkan tanggungjawab pelaksanaan program kerja pada bawahan dengan sedikit kontrol atau tanpa kontrol sama sekali, termasuk dalam penentuan segala kebijakan. Momen-momen ketika pimpinan ini terlibat dalam pengambilan keputusan sendiri atau dengan bawahan sangat sedikit. Pemimpin yang seperti ini dapat dikatakan tidak melakukan fungsinya dengan baik 
baik sebagai perencana, organisator, pemimpin, maupun pengawas. (Chaniago, 2017) menyatakan bahwa fungsi seorang pemimpin dalam pengelolaan organisasi adalah membuat perencanaan (planning), pengorganisasian (organizing), kepemimpinan (actuating/leading), serta pengawasan/pengendalian (controlling).

Di organisasi X, keputusan bersama yang dijalankan secara konsisten adalah yang dikontrol oleh kepala departemen/koordinator baik melalui pesan singkat maupun pertemuan-pertemuan koordinasi. Artinya, setelah diputuskan bersama, maka keputusan yang dilaksanakan secara konsisten oleh anggota yang terlibat dalam pengambilan keputusan adalah yang dikontrol oleh pemimpin dalam pertemuan koordinasi secara langsung yang intens dan tidak hanya melalui fasilitas pesan singkat.

Selain yang telah dipaparkan di atas, ada beberapa temuan lain dari penelitian ini. Pertama, organisasi X merupakan organisasi yang mengedepankan pengembangan bakat minat anggotanya daripada keorganisasiannya. Artinya, bagaimanapun bentuk dan kondisi kepengurusan dalam organisasi tersebut, serta bagaimana koordinasi dan komunikasi yang dijalankan dalam kepengurusan, atau hubungan antar pengurus dalam tubuh kepengurusan, pengembangan bakat minat anggota harus tetap dijalankan. Kedua, sebagian pemimpin di organisasi $\mathrm{X}$ memahami tentang kepemimpinan di organisasi namun tidak dapat menerapkannya. Fakta tersebut tidak bisa dilepaskan kaitannya dari kurang jelasnya pembagian wewenang dan deskripsi tugas untuk masing-masing jabatan di organisasi X. Hal ini akhirnya menyebabkan ketidakjelasan pekerjaan. Salah satu cara supaya para pengurus yang ada di bawahnya menyadari akan tugas dan tanggungjawabnya serta dapat menerapkannya adalah dengan memberikan deskripsi tugas dan pembagian wewenang yang jelas terhadap mereka. Kejelasan wewenang tersebut akan membantu mendeteksi apabila ada yang tidak berjalan sebagaimana mestinya, sehingga persoalan tersebut dapat segera teratasi.

Satu faktor lain yang membantu kepengurusan tetap berjalan di saat pengurus harian tidak dapat menjalankan tugasnya dengan baik adalah keterlibatan para senior yang cukup tinggi di organisasi X. Masih cukup tingginya keterlibatan 
para senior, pengurus maupun anggota non-pengurus masih bisa mendapatkan saran-saran dan pertimbangan ketika atasan mereka tidak dapat melakukannya.

Hasil penelitian ini dianggap dapat digeneralisasikan atau tidak pada organisasi-organisasi lainnya dapat dilakukan setelah membahas karakteristik subyek penelitian itu sendiri. Penjelasan tersebut memberikan gambaran tentang beberapa karakteristik organsiasi X yang menjadi subyek dari penelitian ini, yaitu : bergerak di bidang bakat minat yang mengedepankan eksistensi dan pengembangan diri, merupakan organisasi mahasiswa non-pemerintahan di universitas, berkultur kekeluargaan, dan memiliki sistem keanggotaan yang tidak formal dan tidak mengikat. Oleh karena itu, hasil dari penelitian akan dapat digeneralisirkan pada organisasi yang memiliki karakteristik yang kurang lebih sama.

\section{Kesimpulan}

Dari hasil penelitian yang dilakukan, dapat disimpulkan bahwa gaya kepemimpinan mahasiswa di organisasi mahasiswa $\mathrm{X}$ adalah gaya kepemimpinan partisipatif-kelompok. Hal ini dapat dilihat dari cara berkomunikasi, cara memberi motivasi, penyusunan tujuan, serta pengambilan keputusan yang diambil.

Secara spesifik, komunikasi internal organisasi berjalan ke semua arah namun kurang lancar. Ini menunjukkan bahwa komunikasi dalam organisasi mengarah ke gaya partisipatif kelompok, meskipun kurang ideal. Pemberian motivasi yang banyak digunakan adalah koordinasi dengan bawahan, kedekatan personal, serta pemberian motivasi di bidang kepenulisan pada bawahan. Mengenai penyusunan tujuan, tujuan organisasi disusun oleh ketua umum. Namun ketua umum tidak memberikan penjelasan mengenai maksud dari tujuan tersebut pada para bawahan, sehingga terjadi kebingungan di kalangan bawahan ketika ada yang belum dipahami. Cara pengambilan keputusan dalam organisasi adalah dengan partisipatif kelompok.

Ada temuan-temuan lain yang didapatkan selama proses penelitian. Dua yang paling penting ialah organisasi $\mathrm{X}$ sebagai organisasi bakat minat lebih mengedepankan pengembangan bakat minat dibandingkan keorganisasian. Hal ini membawa implikasi pada saat kepengurusan lemah seperti para periode 2010 
ini,departemen pengembangan bakat minat anggota tetap menjalankan program kerjanya sebagaimana yang direncanakan.

\section{Daftar Pustaka}

Alwisol. (2007). Psikologi Kepribadian. UMM Press.

Bogdan, B., \& Biklen, S. K. (1992). Qualitative Research for Education (Second Edi). Allyn and Bacon.

Bungin, B. (2008). Penelitian Kualitatif. Kencana Prenada Media Grup.

Chaniago, A. (2017a). Pemimpin dan Kepemimpinan. Penerbit Lentera Ilmu Cendekia.

Chaniago, A. (2017b). Teknik Pengambilan Keputusan. Penerbit Lentera Ilmu Cendekia. https://doi.org/10.31227/osf.io/akhqu

Gibson, J. L., Ivancevich, J. M., \& Donelly, J. H. (1997). Organisasi : Perilaku, Struktur, dan Proses, Jilid II. Binarupa Aksara.

Herdiansyah, H. (2019). Wawancara, Observasi, dan Focus Group, Sebuah Instrumen Penggalian Data Kualitatif. PT Rajagrafindo Persada.

Kaswan. (2017). Psikologi Industri dan Organisasi. Penerbit Alfabeta.

Koontz, H., O’Donnel, C., \& Weihrich, H. (1996). Manajemen, Jilid II (Edisi Kede). Penerbit Erlangga.

Krech, D., Crutchfield, R. C., \& Ballachey, E. (1962). Individual in Society. Kogakusha Company.

Moleong, L. J. (2008). Metodologi Penelitian Kualitatif Edisi Revisi. PT Remaja Rosdakarya.

Primastuti, S. K. (2009). Konflik dalam Perkawinan Akibat Kehamilan Pranikah pada Wanita Jawa di Desa Tulungrejo, Kecamatan Bumiaji, Kota Batu. Universitas Negeri Malang.

Wikipedia. (n.d.). Organisasi Mahasiswa. Retrieved October 8, 2021, from https://id.wikipedia.org/wiki/Organisasi_mahasiswa 
Yusuf, A. M. (2019). Metode Penelitian: Kuantitatif, Kualitatif, \& Penelitian Gabungan. Prenadamedia Group. 